\title{
The Effect of Blue Green Algae (Spirulina platensis) Extract in White Rat (RattusNorvegicus) Treated with Excessive Physical Exercise on Leydig Cell Number and Seminiferous Tubules Diameter
}

\section{Dimas Yuzrifar Rhavindra Lazuardi1, Rimayanti², Hardany Primarizky33, Sri Agus Sudjarwo4, Suzanita Utama², and Kadek Rachmawati4}

${ }^{1}$ Student of Veterinary Medicine Faculty,Universitas Airlangga, Surabaya, 60115, Indonesia ${ }^{2}$ Veterinary Reproduction Department of Veterinary Medicine Faculty, Universitas Airlangga, Surabaya, 60115, Indonesia

${ }^{3}$ Veterinary Clinical Department of Veterinary Medicine Faculty, Universitas Airlangga, Surabaya, 60115, Indonesia

${ }^{4}$ Veterinary Basic Department of Veterinary Medicine Faculty, Universitas Airlangga, Surabaya, 60115, Indonesia

Corresponding Author:

Rimayanti

Received: 03 October 2017 Accepted: 10 October 2017 Published: 29 November 2017

Publishing services provided by Knowledge $\mathrm{E}$

(c) Dimas Yuzrifar Rhavindra Lazuardi et al. This article is distributed under the terms of the Creative Commons

Attribution License, which permits unrestricted use and redistribution provided that the original author and source are credited.

Selection and Peer-review under the responsibility of the VMIC Conference Committee.

\section{Abstract}

The aim of this study was to investigate the effect of Spirulino platensis extract on the amount of Leydig cells, amount of necrotic Leydig cells, and diameter of seminiferous tubules of rats treated with excessive physical exercise. The excessive physical exercise was done through 60 minutes of swimming for 35 days. Twenty white male rats were randomly divided into five groups i.e C-, control group, C+, a group was only receive swimming, $T_{1}, T_{2}$, and $T_{3}$ was received 300,600, and 1200 $\mathrm{mg} / \mathrm{kg}$ BW of Spirulina platensis and swimming. Spirulina platensis extract was given orally once a day before swimming. ANOVA followed by Duncan analysis showed significant differences among treatments. Excessive physical exercise influenced on male reproduction system through decreasing the amount of Leydig cells. The conclusion was a dose of $1200 \mathrm{mg} / \mathrm{kg}$ BW of Spirulina platensis extract could maintain the amount of Leydig cells, protected the Leydig cells from becoming necrotic, and increased the diameter of seminiferous tubules.

Keywords: Rattus Norvegicus, Spirulinaplatensis, excessive physical exercise, Leydig cells, seminiferous tubules diameter.

\section{Introduction}

Physical activity has been recognized as an important lifestyle factor, which contributes to good health and delays the onset of many diseases later in life [1]. By doing exercise 
in a proper way can give good effects to prevent many diseases such as coronary heart disease, hypertension, obesity, heart failure, depression, and diabetes mellitus [2]. The regular exercise can prevent many severe diseases for human and animal but it must in a proper way. Most data indicate that excessive and chronic oxidative stress may cause cellular damage [3]. The side effects on this excessive exercise can cause increasing oxidant in the body. If this oxidant could not be neutralized by the body, it can be defined as oxidative stress [4].

When free radicals overwhelm antioxidant defenses, the cells are damaged. This damage is called oxidative stress [5]. But, if the formations of free radicals are increased induced by excessive physical exercise, the amount of free radicals will exceed the ability of the defense system body and cannot be neutralized by antioxidants in the body. This could damage in to the cell membrane, muscle, and tissues [6].

Free radical is a group of an atom that has unpaired electrons, unstable, and highly reactive those tend to attack cells, leading damage cell itself [7]. In the excessive physical exercise, the free radicals formed primarily are Reactive Oxygen Species (ROS), through electron transport chain [8]. In the report of [1], high concentrations of ROS could damage organs, tissue and cells included male reproduction system. Reactive oxygen species were dangerous for polyunsaturated fatty acid leading lipid peroxidation.

According to [9], the testicular interstitial tissue is the place of Leydig cells as a producer of testosterone that has a role in the differentiation process of spermatozoa. Excessive physical exercise may cause interference on the endocrine systems, such as increased cortisol levels and decreased testosterone levels [10]. CRH induce increased of ACTH leading to activation of cortisol. Activation of cortisol may cause disturbance of testosterone [11].

Spirulina platensis is a blue-green alga belongs to the group cyanobacterium [12]. It is rich in proteins, lipids, carbohydrates, $\beta$-carotene, riboflavin, $\alpha$-tocopherol and $\alpha$ linoleic acid [13]. In the research of [14], the addition of Spirulina plantensis in diet can have beneficial health effect due to antioxidant properties. It is rich in proteins, lipids, carbohydrates, $\beta$-carotene, riboflavin, $\alpha$-tocopherol and $\alpha$-linoleic acid.Protective effect of spirulina plantesis pre-treatment could reduce the lipid peroxidation, histopathological changes of testes and spermatozoa abnormalities [13].

In the report of [15], antioxidants present in Spirulina platensis ( $C$-phycocyanin and $\beta$ carotene) acts as a free radical scavenger and improve the testicular condition. Vitamin 
C (ascorbic acid) and Vitamin E ( $\alpha$-tocopherol) also contribute to the support as an antioxidant in the testis with protecting role from the oxidative damage [16].

\section{Materials and methods}

The experimental animal used in this study are 20 healthy Wistar strained male rats (Rattus norvegicus) at age of 2-3 month, and the weight about 150-200 grams.

Ethanolic extract of Spirulina platensis obtained by means of maceration method. Materials used in this research included Spirulina platensis powder obtained from Yogyakarta, ethanol 96\%for maceration, and rotovapor.

Chemicals used in histopathological preparation are 70\%, 80\%, 90\% and 96\% alcohol, xylol, paraffin, entellan, and Hematoxylin Eosin.

The equipment used for the treatment includes a scale to measure the weight of rat, five units of rat cage in the form of rectangular plastic tubs covered with wire, a container for feed and drink, $3 \mathrm{ml}$ tuberculin syringes, feeding tube, a bucket of water measuring with a diameter of $35 \mathrm{~cm}$.

The equipment used for the Spirulina platensis extract solution is beaker glass, digital scales, spoon, a bottle of extract, sterile aquadest, and $0.5 \% \mathrm{Na}-\mathrm{CMC}$ as suspension.

20 white male rats reared in Animal Laboratory of Experimental Animal at Medicine Faculty of Universitas Airlangga, randomized by lottery and were divided into five groups, and then adapted to the environment for one week. In the second week of experimental, T(1), T(2), and T(3) adapted to feeding orally of Spirulina platensis extract. In the third week of experimental, rats have been treated with swimming as excessive physical exercise respectively for 35 days, feeding and drinking given twice a day ad libitum.

\subsection{Dose and Treatment}

The dose of Spirulina platensis extract were $300 \mathrm{mg} / \mathrm{kg}$ bw [13], $600 \mathrm{mg} / \mathrm{kg}$ bw, and $1200 \mathrm{mg} / \mathrm{kg}$ bw [17]. In this study, researchers used five groups of treatments:

Negative control ( $C$-): Neither received Spirulina platensis extract not swimming

Positive control $\left(C_{+}\right)$: Rats carry out swimming for 60 minutes

Treatment 1 (T1): Received $300 \mathrm{mg} / \mathrm{kg}$ bw Spirulino platensis extract and swimming for 60 minutes 
Treatment 2 (T2): Received $600 \mathrm{mg} / \mathrm{kg}$ bw Spirulina platensis extract and swimming for 60 minutes

Treatment 3 (T3): Received $1200 \mathrm{mg} / \mathrm{kg}$ bw Spirulina platensis extract and swimming for 60 minutes

The treatments administered using $3 \mathrm{ml}$ disposable tuberculin syringe with Feeding tube by intragastric gavage. The experimental treatment has been done every day for 35 days. The next day from the last treatment, treatment groups of $C(-), C(+), T(1), T(2)$ and $\mathrm{T}(3)$ sacrificed by doing anesthesia (ether) and the testes have been collected.

\subsection{Leydig cells observation and seminiferous tubules diameter measurement}

The data observed from the amount of Leydig cell, the amount of Leydig cell undergoing necrotic, and diameter of seminiferous tubules. Each histopathological slide has been observed with five different views randomly. The evaluation of Leydig cells amount has been observed per field of view in each histopathological slide. Necrotic evaluation has seen from the changes of Leydig cells' nucleus, which may change into pycnosis, karyorrhexis, or karyolysis. The slide was observed under a microscope at 400x magnification.

The diameter measured on the shortest distance between two opposite points on the shortest of the central line and measure the furthest distance between two opposite points that perpendicular, and then divided by two. The measurement result is in micrometer at 100x magnification. Every slide measured by ten seminiferous tubules and then divided by two [18].

\subsection{Data Analysis}

The design of this research is using Completely Randomized Design with 5 treatments and 4 replicates. Data of research were analyzed with Analysis of Variance (ANOVA) followed by Duncan's test. Statistical analyzer used Statistical Program Service and Solution (SPSS) 22.0 for windows

\section{Results}




\subsection{Amount of Leydig cells}

Based on the result, there are significant differences between treatments after counting the number of Leydig cells $(p<0.05)$. Between $C+$ and the other groups such as $C-$, $T_{1}, T_{2}$, and $T_{3}$ (Table 1). $C+$ with mean value $5.95 \pm 0.10$. Each group has a mean value of Leydig cells there are C- with mean value $12.5 \pm 1.88$, T1 with mean value $9.05 \pm$ 1.45 , T2 with mean value $10.50 \pm 3.38$, and T3 with mean value $12.20 \pm 1.72$.

\subsection{Amount of Necrotic Leydig cells}

Based on the result, showed a significant difference $(p<0.05) . C+$ has a significant difference with the others group such as $T_{1}, T_{2}, T_{3}$, and C- (Table 2). $T_{1}$ and $T_{2}$ group showed no significantly different, each group has mean value $38.80 \pm 2.09$ and 36.5 \pm 1.56 . T3 and C- group showed no significantly different, each group has mean value $14.27 \pm 4.14$ and $13.09 \pm 4.87$.

\subsection{Seminiferous tubules diameter}

C- has mean value $439.0 \pm 18.9$ significant difference with the others group such as $T_{1}, T_{2}, T_{3}$, and $C_{+}$(Table 3). Based on the mean value, between $T_{2}$ and $T_{3}$ group, there is an increase of diameter number $297.0 \pm 11.6$ and $354.9 \pm 26.1$. T3 group has higher mean value than $C_{+}, \mathrm{T}_{1}$, and $\mathrm{T}_{2}$.

\subsection{Discussion}

The amount of Leydig cells in each testis are related to the total volume of Leydig cells and with the content of LH, if LH content is decreased then the amount of Leydig cells are decreased too [19]. Excessive physical exercise could affect the endocrine system, which were FSH and LH. FSH and LH were gonadotropin hormone stimulating spermatogenesis in the male reproductive system [20]. FSH and LH were produced and secreted by the gonadotropic cells of the anterior pituitary, which were derivate by $\mathrm{GnRH}$. When excessive physical exercise, $\mathrm{CRH}$ induce increased of ACTH leading to activation of cortisol. CRH induce $\beta$-endorphin and suppressing GnRH leading inhibition of reproductive axis, which is a potent negative regulator of LH in Leydig cells causing decreased the level of LH [11]. So the decreasing of the amount of Leydig cells because 
TABLE 1: Effect of Spirulina platensis extract of the amount of Leydig cells, the amount of Leydig cells undergoing necrotic, and seminiferous tubules diameter in white male rat (Rottus norvegicus). (Mean \pm $\mathrm{SD})$

\begin{tabular}{l|c|c|c|}
\hline Tratment & $\begin{array}{c}\text { Amount mount of Leydig } \\
\text { cells }\end{array}$ & $\begin{array}{c}\text { Amount of necrotic Leydig } \\
\text { cells }(\%)\end{array}$ & $\begin{array}{c}\text { Seminiferous tubules } \\
\text { diameter }(\mu \mathrm{m})\end{array}$ \\
\hline $\mathrm{C}(-)$ & $12.25 \pm 1.88^{b}$ & $13.09 \pm 4.87^{a}$ & $439.0 \pm 18.97^{c}$ \\
\hline $\mathrm{C}(+)$ & $5.95 \pm 0.10^{a}$ & $89.19 \pm 1.40^{c}$ & $282.7 \pm 16.25^{a}$ \\
\hline T1 & $9.05 \pm 1.45^{b}$ & $38.80 \pm 2.09^{b}$ & $297.5 \pm 20.68^{a}$ \\
\hline T2 & $10.50 \pm 3.38^{b}$ & $36.51 \pm 1.56^{b}$ & $297.0 \pm 11.61^{a}$ \\
\hline T3 & $12.20 \pm 1.72^{b}$ & $14.27 \pm 0.34^{a}$ & $354.2 \pm 26.16^{b}$ \\
\hline a,b, and c : Different superscript in the same column showed significant differences $(p<0.05)$
\end{tabular}

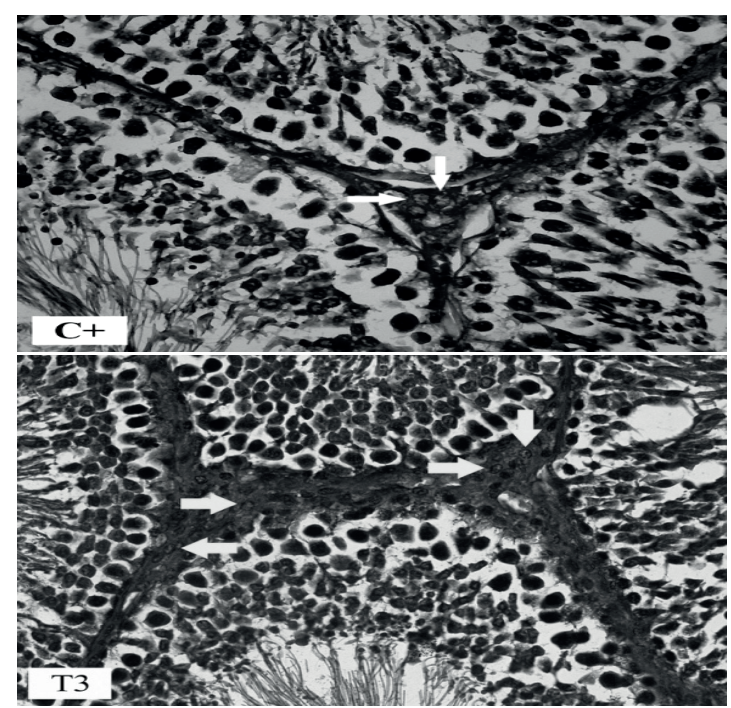

Figure 1: Comparison of a number of Leydig cells between $C+$ and $T_{3} . C+$ showed decreasing of the Leydig cells amount.

of LH content is decreasing too. C+ group which did not receive Spirulina platensis extract showed decreasing of Leydig cells amount (Figure 1).

Leydig cells are large, polygonal, eosinophilic cells that typically contain lipid droplets. The cytoplasm of Leydig cells also contains many inclusions like lipid [21]. This was related to the statement of [1], high concentrations of ROS could damage organs, tissue and cells included male reproduction system. Reactive oxygen species were dangerous for polyunsaturated fatty acid leading lipid peroxidation. T3 is group received a dose of $1200 \mathrm{mg} / \mathrm{kg}$ bw of Spirulina platensis extract and it could protect Leydig cells against necrotic in testes (Figure 2).

The result of diameter measurement of seminiferous tubules and data analysing showed a significant difference $(p<0.05)$. T3 which received dose $1200 \mathrm{mg} / \mathrm{kg}$ bw of 


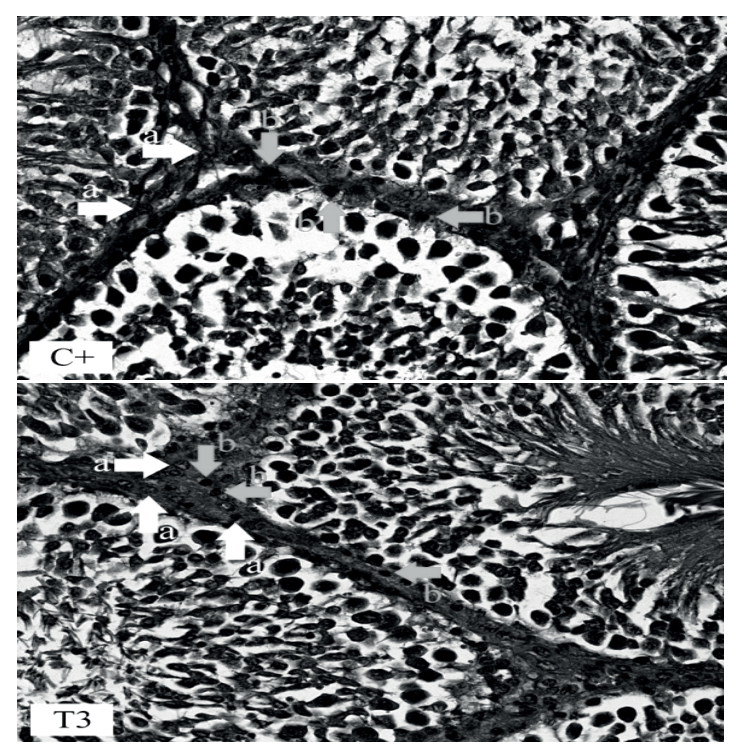

Figure 2: Comparison of a number of necrotic Leydig cells between C+ and T3. Normal Leydig cells (a) and Necrotic Leydig cells (b). T3 showed decreasing the amount of necrotic Leydig cells.
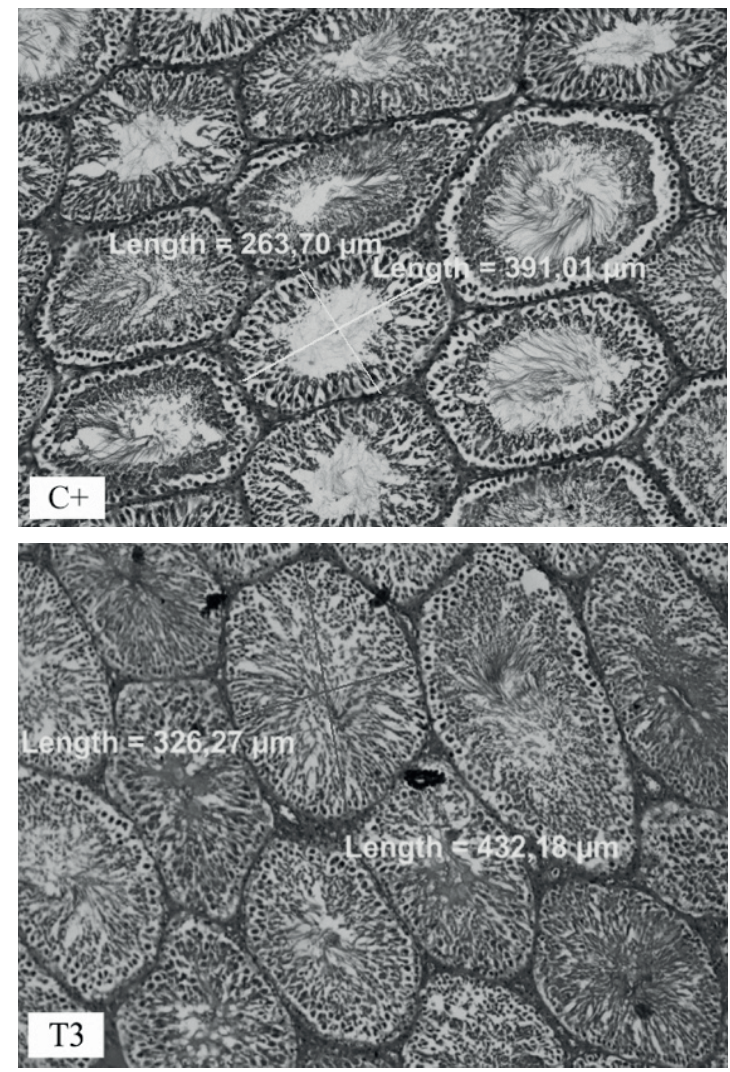

Figure 3: Comparison on the seminiferous tubules diameter between $\mathrm{C}+$ and $\mathrm{T}_{3}$. T3 showed increasing of the seminiferous tubules diameter.

Spirulina platensis has the optimal result among each group. It could be indicate that 
administration of Spirulina platensis extract at a dose of $1200 \mathrm{mg} / \mathrm{kg}$ bw has increased the diameter of seminiferous tubules (Figure 3).

This was related to the research of [22]Spirulina platensis extract could maintain on the number of spermatogenic cells in seminiferous tubules. In addition to [23] Anindita and Sutyarso (2012), Diameter of seminiferous tubules is affected by spermatozoa production.

\section{References}

[1] Manna, I., K Janna and P K Samantha. 2003. Effect of Different Intesities of Swimming Exercise on Testicular Oxidative Stress and Reproductive Dysfunction in Mature Male Albino Wistar Rats. Indian Journal of Experimental Biology. 42: 816822

[2] Haskell, William L., I-Min Lee, Russell R. Pate, Kenneth E., Powell, Steven N. Blair, Barry A. Franklin, Caroline A. Macera, Gregory W. Heath, Paul D. Thompson, Adrian Bauman. 2007. Physical Activity and Public Health Updated Recommendation for Adults. American College of Sports Medicine and the American Heart Association. Available from: http://circ.ahajournals.org. Accessed: May, $21^{\text {th }} 2015$.

[3] Singh U., Jialal I. 2006. Oxidative stress and atherosclerosis. Pathophysiology;13: 129-42.

[4] Hairrudin, Dina H., and Yulestrina W. 2012. Aktivitas Fisik Berat Menyebabkan Degenerasi Sel Hepatosit melelui Mekanisme Stres Oksidatif. Jurnal kedokteran Brawijaya. 27: 61-65.

[5] Radak Z., Zhao Z., Koltai E. 2012. Oxygen Consumption and Usage During Physical Exercise: The Balance Between Oxidative Stress and ROS-Dependent Adaptive Signaling. Antioxidant and Redox Signaling. 18: 1208-1246

[6] Cooper, K., Baraas, Faisal, Wibowo, Singgih, M. 2001. Sehat Tanpa Obat: Empat Langkah Revolusi Antioksidan Yang Mengubah Hidup Anda. Bandung: Kaifa.

[7] Sugianto, Nanik Lidyawati. 2011. Pemberian Jus Delima Merah (Punica granatum) Dapat Meningkatkan Kadar Glutathion Peroksidase Darah Pada Mencit (Mus Musculus) dengan Aktivitas Fisik Maksimal [Tesis]. Denpasar: Universitas Udayana.

[8] Arsana, I.N. 2014. Ekstrak Kulit Buah Manggis (Garcinia mangostana L.) dan Pelatihan Fisik Menurunkan Stres Oksidatif Pada Tikus Wistar (Rattus norvegicus) Selama Aktivitas Fisik Maksimal [Dissertation]. Universitas Udayana.

[9] Junquiera, L.C., and Carneiro, K. 2005. Basic Histology Test and Atlas. Department of Cell and Developmental Biology. Institute of Biomedical Sciences. Sao Paolo. Edisi 
11. Chapter 21.

[10] Maffetone. P. 2007. The Overtraining Syndrom. International Sport Sciences Association. Accesed: August, $13^{\text {th }} 2015$.

[11] . Mastorakos, G., Maria P., Evanthia D.K., Georga P.C. 2005. Exercise and The Stress System. Hormones. 4: 73-89.

[12] Spolaore, P., Joannis, C,. Duran, E dan Isambert, A. 2006. Commercial Applications of Microalgae. Journal of Bioscience and Bioenginering, Vol 101: 87-96 pp.

[13] El-Desoky, Gaber E., Samir A. Bashandy, Ibrahim M. Alhazza, Zeid A. Al-Othman, Mourad A. M. Aboud-Soud and Kareen Yusuf. 2013. Improvement of Mercuric Chloride-Induced Testis Injuries and Sperm Quality Deteriorations by Spirulina platensis in Rats. Public Library of Science. 8: 1-9.

[14] Ferreira-Hermosilo A, Torres-Durran PV, Shamosh-Halabe S, and Juarez-Oropeza MA. 2011. Biological Effect of Spirulina and Current Research on Its Antioxidant Activity. Toctli Revista Internacional de Ciencia y Technologia Biomedica. 2: 1-13.

[15] 'Shaikh, H., VK Shrivastava, R. Shrivastava, M. Amir. Chemo-Protective Effect Of Turmeric And Spirulina On Cisplatin Induced Toxicity In Reproductive System Of Male Albino Rat, Rattusnorvegicus. Indo American Journal Of Pharmaceutical Research. 3: $7257-7264$

[16] Vijayprasad, Sanghishetti., Ghongane BB, and Nayak BB. 2014. Effect of Vitamin C on Male Fertility in Rats Subjected to Forced Swimming Stress. Journal of Clinical and Diagnostic Research. 8: 5-8.

[17] Hutadilok-Towatana, N., W. Reanmongkol, S. Satitit, P. Panichayupakaranant and P. Ritthisunthorn. 2008. A subchronic toxicity study of Spirulina platensis. Food Science Technology Research. 14: 351-358

[18] Aprilliani, M., Nurcahyani, N., Busman, H. 2013. Efek Pemaparan Kebisingan Terhadap Jumlah Sel-Sel Spermatogenik Dan Diameter Tubulus Seminiferus Mencit (Mus musculus L.). Seminar Nasional Sains \& Teknologi V. Lampung, Indonesia.

[19] Johnson, L. and Thompson, Jr.D.L. 1986. Seasonal variation in the total volume of Leydig cells in stallion is explained by variation in cell number rather than cell size. Biology of Reproduction. 52: 971-79.

[20] Sonjaya, H. 2012. Dasar Fisiologi ternak. IPB Press. Bogor

[21] Siregar, J. H. 2009. Pengaruh Pemberian Vitamin C terhadap Jumlah Sel Leydig dan Jumlah Sperma Mencit Jantan Dewasa (Mus musculus L.) yang Dipapari Monosodium Glutamat (MSG) [Tesis]. Program Pasca Sarjana. Universitas Sumatra Utara. Medan. 
[22] Wahyu R. 2016. Effect of Spirulina platensis On the Number of Spermatogenic Cells in the Seminiferous Tubules of Rat (Rattus norvegicus) With Excessive Physical Exercise [Thesis]. Universitas Airlangga. Surabaya

[23] Anindita dan Sutyarso. 2012. Pengaruh Pemberian Vitamin C Terhadap Berat Testis, Jumlah Sel Leydig, dan Diameter Tubulus Seminiferus Mencit (Mus musculus) Jantan Dewasa Yang Diinduksi Monosodium Glutamat. Jurnal Fakultas Kedokteran Universitas Lampung. 36-48. 